\title{
PREVALENCE OF BURNOUT SYNDROME AMONG CLINICAL NURSES WORKING AT STATE HOSPITAL, IJAYE, ABEOKUTA, OGUN STATE, NIGERIA
}

\author{
Sodimu Jeminat Omotade ${ }^{1}$, Dr. Ngozi Okafor ${ }^{2}$, Fadipe Ololade Omolayo ${ }^{3}$ \\ and Mosuro Oluremi Tajat ${ }^{4}$ \\ ${ }^{1}$ School of Nursing, Abeokuta, Ogun State, Nigeria. \\ ${ }^{2}$ School of Nursing, Babcock University, Ilisan Remo, Ogun State, Nigeria \\ ${ }^{3}$ Lagos State University Teaching Hospital (LASUTH) \\ ${ }^{4}$ State Hospital, Ijaiye, Abeokuta, Ogun State
}

Cite this article:

Sodimu J.O., Ngozi O., Fadipe O.O., Mosuro O.T. (2021), Prevalence of Burnout Syndrome among Clinical Nurses Working at State Hospital, Ijaye, Abeokuta, Ogun State, Nigeria. African Journal of Health, Nursing and Midwifery 4(5), 85-101. DOI: 10.52589/AJHNM-

JXC09CBZ.

\section{Manuscript History}

Received: 20 July 2021

Accepted: 12 Aug 2021

Published: 23 Aug 2021

Copyright $\odot 2020$ The Author(s). This is an Open Access article distributed under the terms of Creative Commons AttributionNonCommercial-NoDerivatives 4.0 International (CC BY-NC-ND 4.0 ), which permits anyone to share, use, reproduce and redistribute in any medium, provided the original author and source are credited.
ABSTRACT: Even though burnout syndrome is detected in professionals from various areas, prevalence is particularly high in service and care workers, especially health and care ones. Among those, nurses have been the subject of several studies, because they experience constant stressful labour situations, working in direct contact with patients who have different expectations and degrees of suffering. It is, therefore, necessary to conduct a study to determine the prevalence of the symptoms of burnout among nurses in hospitals in an effort to anticipate the negative impact of burnout on hospital nursing services. Consequently, this study aims to determine the level, knowledge and prevention among clinical nurses. A descriptive design was adopted for this study which was conducted in State Hospital, Ijaye, Abeokuta. A total of 100 respondents were used for the study, a stratified sampling technique was used to select the participants. A modified, structured, closed-ended questionnaire was used. Analysis was presented in tables, charts and percentages. Nearly all the causes listed in the questionnaire were seen as factors causing burnout in clinical nurses $199 \%$ of working long hours). 96\%: from patients and families. Furthermore, it was found out that the majority of the nurses agreed to items listed in the questionnaire as things a nurse can do to prevent burnout, establishing social support; $94 \%$, set goals for self; $99 \%$ etc. This implies that the majority of the nurses know what they can do to prevent burnout. Aside from free study grants, job opportunities that are most likely to attract young people, what can be done to retain nurses are to improve job satisfaction, patient safety, quality of health care and quality of life for both nurses and patients.

KEYWORDS: Perception, Burnout, Clinical, Syndrome, Emotional exhaustion 


\section{INTRODUCTION}

Nurses are commonly exposed to stress due to work overcharge. In this context, burnout syndrome can be defined as long-term work stress resulting from the interaction between constant emotional pressure associated with intense interpersonal involvement for long periods of time and personal characteristics. Frequent burnout syndrome symptoms include emotional exhaustion and the development of negative attitudes and feelings towards work colleagues as well as to their own professional achievement (Harrowing, 2011).

Even though burnout syndrome is detected in professionals from various areas, prevalence is particularly high in service and care workers, especially health and care ones. Among those, nurses have been the subject of several studies, because they experience constant stressful labour situations, working in direct contact with patients who have different expectations and degrees of suffering. For instance, a study conducted in Europe in 2011 by Van Der Doef, M., Mbazz, F.B., Verhoeven, C., showed that approximately 30\% of nurses surveyed reported being exhausted or fatigued due to work activities. In addition, a British study found that approximately $42 \%$ of nurses in England reported being suffering from burnout, whereas in Greece approximately $44 \%$ of nurses reported a feeling of dissatisfaction at work and a desire to leave work. Lower prevalence was reported in a survey in Germany, which estimated that $4.2 \%$ of that worker population was affected by burnout (Schmidt \& Diesel, 2012).

However, few studies in Brazil (Schmidt and Diesel, 2012), have investigated only nurses. In most cases, the number of professionals in the institutions investigated is relatively small, leading to the joint study of nurses, technicians, and assistants, whose professional activities differ in nature, complexity, and emotional overload. Thus, it is difficult to determine the exact prevalence of this condition among nurses in Brazil. Moreover, studies on burnout syndrome in Brazil (Baldonedo-Mosteiro, 2019) have largely overlooked high-quality institutions that constantly strive to obtain health care quality certifications. Thus, it is not known, for instance, whether the prevalence of the syndrome among nurses in high-quality institutions differs from that observed in other institutions. That knowledge is necessary to identify factors associated with the onset of the syndrome and to develop plans for prevention and control.

In this study, it was investigated that the prevalence/propensity of burnout syndrome in clinical nurses, and the factors related to burnout syndromes associated, such as socio-demographic characteristics, workload, social and family life, leisure activities, extra work activities, physical activities, and work-related health problems. Nurses with and without burnout syndrome or burnout propensity were compared.

Individuals suffering from burnout usually manifest psychosomatic problems (weakness and insomnia), emotional problems (anxiety and depression), attitude problems (hostility, apathy and distrust) and behavioural problems (aggressiveness, irritability and isolation), among other problems (Adriaenssens et al., 2012; Jansson Frojmark and Lindblom, 2011; Leape et al., 2012). Moreover, burnout affects nurses' workplaces, both public and private (more sick leave, diminished work effectiveness, more absenteeism, etc.). The users of healthcare services are also affected as the quality of health care deteriorates (Brinkert, 2010, Clausen et al., 2012; Schmidt and Diesel, 2012).

Because of the nature of their job, nurses are at risk of developing burnout syndrome (Lundmark V.A, 2010). Recent studies relate high levels of emotional exhaustion to an increase 
in morbidity associated with related psychiatric disorders (Renzi C, Pietro C, Tabolli S, 2012). Other studies report high prevalence rates of emotional exhaustion and depersonalization accompanied by low levels of personal accomplishment among nursing personnel (Al-Turki, 2010). All of these research studies found that the work environment and the nurses' personal and social situation have an impact on the advent and potentially on the development of the disorder (Albaladejo R., Villanueva P., Ortega P, 2004).

As Vargas C, Aguayo R, Fernadez R. (2014) and Pereda-Torales L, Marquez C (2009) argue any evidence of the protective and risk factors for burnout are of great interest to the scientific community. More information about these factors is needed to prevent burnout syndrome and to determine the most appropriate clinical interventions when the disorder appears. Thus, research in the field addresses two types of relevant variables: personal variables (sociodemographic and personality-related variables) and organizational variables (those pertaining to the occupational environment of the participating nurses) (Aydemir and Icelli, 2013).

The process of occupational burnout develops slowly, its initial symptoms are discreet, they increase progressively, and they become manifest suddenly and with great power. Burnout syndrome constitutes a serious personal and social problem whose cause lies in the workplace or is work-related. Its consequences concern the mental, emotional, physical, professional, and family sphere; thus, it is not only the worker experiencing burnout who suffers but also his or her environment. A nurse is constantly involved in the patient's illness, life problems, and quite often she accompanies the patient in the dying process. It poses great emotional requirements for him/her, the consequence of which is stress. Its accumulation and the lack of the ability to release it leads to chronic occupational stress, which is destructive for a nurse, bringing about lowered self-esteem and quality of work, and it affects contact with patients. Many women working in the capacity of a nurse become burned out due to a lack of appreciation and recognition. Low wages generate disappointment and frustration among nurses, while responsibility in the workplace leads to burnout syndrome increasing year after year. As a result, multi-dimensional burnout syndrome appears (Baldonedo-Mosteri, 2019).

Work should be a source of happiness and a sense of fulfilment in life and a sense of job satisfaction to everyone. Satisfaction upholds the employee's readiness to work, which is why the most important goal of any actions in this area is to strive to accompany employees at all times. Burnout syndrome is a problem that we have to talk about because it is a serious threat to the employee's health. Knowledge about its existence is a key to proper decisions being made by the employer to create a friendly work environment (Renzi C, Pietro C, Tabolli, S, 2012).

Growing recognition of job stress leading to dissatisfaction among registered nurses in Nigerian hospitals has contributed to current problems with recruitment and retention of nurses in the country in general but more particularly in some states. If nurse administrators identify factors influencing nurses' job satisfaction in government hospitals and implement strategies to address these factors, nurses' turnover rate will decrease and recruitment and retention rates will increase. Moreover, burnout among nurses has a negative effect on the quality of patient care (Albaladejo et al, 2014). Several studies have demonstrated various components of burnout among nurses in developed countries of the world. However, not much has been done in a poor resource, multiethnic, and culturally laden country like Nigeria. There is a dearth of information on this subject matter, hence the need for this study. 
Several other studies (Vargas et al, 2014), also found that the occurrence of burnout in nurses can cause mental fatigue, worry, decreased motivation, commitment and performance, an increase in absentee level and resignation; and decreased job satisfaction and productivity. The condition of burnout in nurses will have a negative impact on the quality of nursing care provided to patients and families, making relationships between colleagues become destabilized and promote negative feelings toward patients, the job and the organization. Hence, burnout will have the effect of decreasing the quality of services, leading to adverse patient outcomes and medical errors.

Based on the previous explanation, it is, therefore, necessary to conduct a study to determine the prevalence of the symptoms of burnout among nurses in hospitals in an effort to anticipate the negative impact of burnout on hospital nursing services.

\section{LITERATURE/THEORETICAL UNDERPINNING}

\section{Professional Burnout Among Nurses}

A total of 26 articles examined burnout among nurses in Ghana, South Africa, Nigeria, Kenya, Tanzania, Uganda, Cameroon, Namibia, and Zimbabwe.

The majority of studies were conducted in South African $(N=13)$ and Nigerian $(N=8)$ nursing populations. Of the 26 articles, a total of 20 studies used the Maslach Burnout InventoryGeneral Survey (MBI-GS), emotional exhaustion subscale to measure burnout.

Two studies used the Oldenburg Burnout Inventory, one study used the burnout subscale of the ProQOL, and one study used first-hand coding by an observer according to the ExhaustionDisengagement Model, which uses job demand and resources to identify exhaustion and disengagement. One study used the Executive Burnout Scale, which was developed in Nigeria as a culturally sensitive tool to measure burnout. One study did not specify the burnout measure used. A total of 5 studies did not report measured burnout levels in the study population.

High levels of reported burnout were found in nursing populations. For example, in a large study of nurses at national referral hospitals in South Africa $(N=1187), 45.8 \%$ of participants reported high levels of burnout on the emotional exhaustion subscale of the MBI. Among hospital nurses in Nigeria $(N=270), 39.1 \%$ had burnout on the emotional exhaustion subscale of the MBI, $29.2 \%$ on the depersonalization subscale, and $40.0 \%$ on the reduced personal accomplishment subscale. In a population of nurses at private and public hospitals in Kenya, Tanzania, and Uganda, $(N=309), 32.1 \%$ reported burnout on the MBI. Among nursing populations in South Africa, burnout was associated with high workloads and a lack of support.

In their study of registered nurses in South Africa, Van der Colff and Rothmann (2009) showed that the nurses' experience of depletion of emotional resources and feelings of depersonalization were associated with stress due to job demands and a lack of organizational support, focus on and ventilation of emotions as a coping strategy, and a weak sense of coherence. The study of HIV/AIDS health care workers by Dageid, Sedumedi and Duckert (2007) also conducted in South Africa reported that negative emotional experiences were dominant. 


\section{Conceptual Framework}

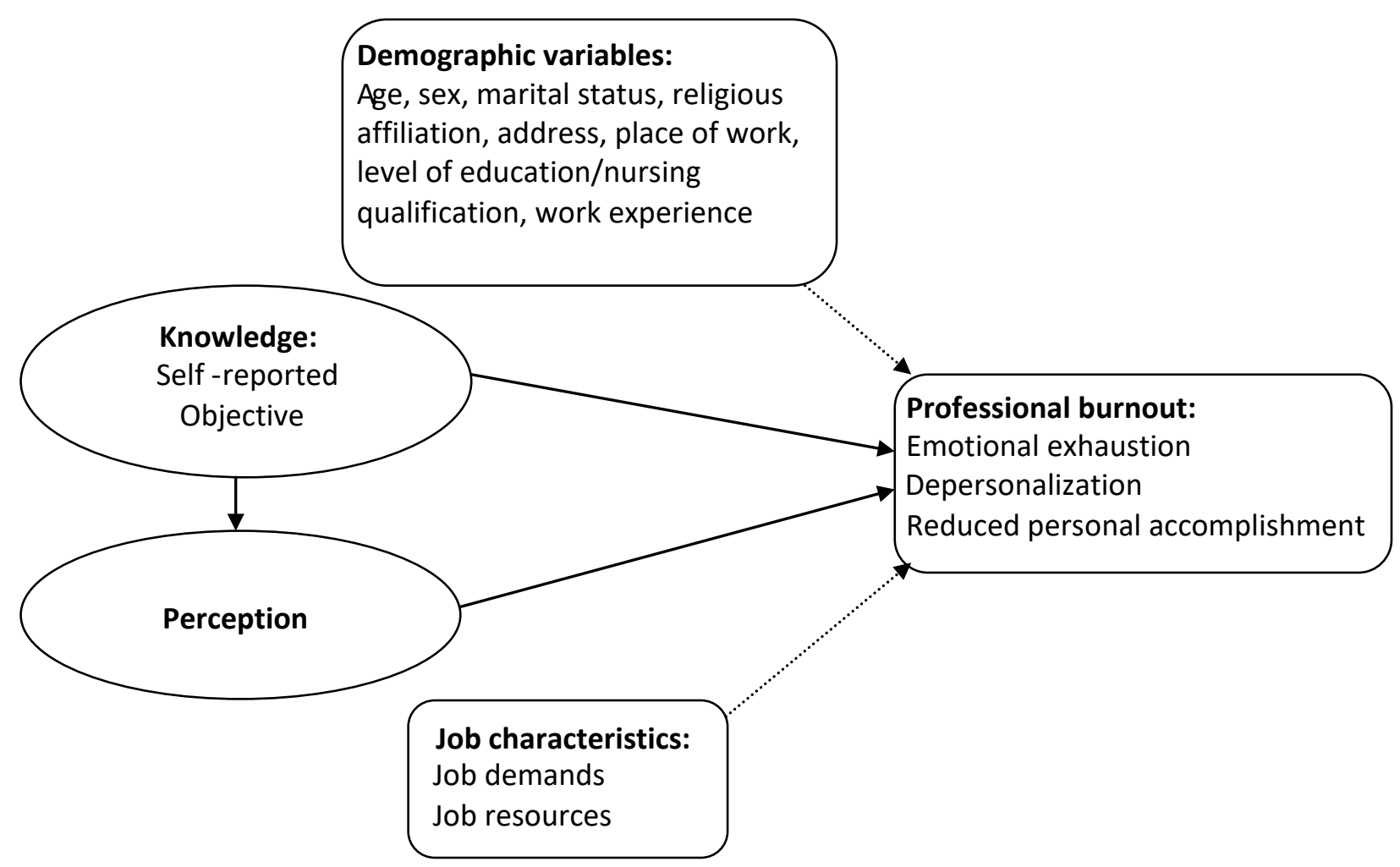

\section{A Conceptual Framework for the Relationship between Knowledge, Perception and Professional Burnout By Christine Maslach}

In the conceptual framework illustrated above, knowledge and perception were depicted to influence professional burnout. Knowledge was defined as awareness/familiarity of burnout from a self-reported and objective perspective; perception is what nurses regard as the experience of burnout. Professional burnout was defined as emotional exhaustion, depersonalization and reduced personal accomplishment. This study adhered to Christine Maslach's work that described a sequential progression of burnout over time.

The framework postulated that the knowledge and perception of nurses directly affected their experience of burnout. Thus, the nurses' awareness of the sequence affects their perception of job burnout. However, this relationship may be modified by the nurses' demographics and job characteristics. 


\section{METHODOLOGY}

\section{Research Design}

A descriptive design was adopted for this study. This was considered appropriate because it reported a cross-sectional of nurses of various units and cadres at the same time in the way they actually exist.

\section{Research Setting}

The study was conducted at State Hospital Ijaye, Abeokuta South local government area, Abeokuta, Ogun state. State Hospital Ijaye, Abeokuta represents a secondary health care facility where a good number (154) of nurses work. It represents a secondary tertiary health care facility that serves as a referral centre for the Abeokuta health zone which comprises of 9 other health facilities and a hospital support centre. The hospitals render primary and secondary health care services which include: General out-patient clinic, Children out-patient clinic, Infant and child welfare clinic, Ante-natal services, Family planning services, immunization services, HIV/AIDS-Related activities and Chest clinic.

Secondary health care services include Orthopedic/trauma surgery, General surgery, Internal medicine, Ophthalmology, Obstetrics and gynaecology, Physiotherapy, Radiology services, Laboratory services and Pharmaceutical services.

The hospital has a capacity of 250 beds and cots. It was accredited by the National Health Insurance Scheme (NHIS) as a primary and secondary provider. The hospital is supervised by Ogun state Hospital Management Board.

\section{Population}

The nursing service department has a total of 154 nurses working in the hospital distributed as follows; chief matrons (59), senior matrons (14), matron I (27), matron II (23), senior nursing staff (13) and nursing staff (18).

\section{Sampling Techniques}

The sample size was determined using Yamane's Formula in State hospital; the basic formula is:

$\mathrm{n}=\frac{\mathrm{N}}{\left[1+\mathrm{N}(\mathrm{e})^{2}\right]}$

Where $\mathrm{n}=$ sample size

$\mathrm{N}=$ population size

$\mathrm{E}=$ Error margin $=0.1$

$\mathrm{n}=\frac{154}{\left[1+154(0.1)^{2}\right]}$ 


$$
\begin{aligned}
& \mathrm{n}=\frac{154}{1+154(0.01)} \\
& \mathrm{n}=\frac{154}{155(0.01)} \\
& \mathrm{n}=\frac{154}{1.55} \\
& \mathrm{n}=99.53 \underline{\Omega} 100
\end{aligned}
$$

A stratified sampling technique was used to select 100 nurses from 154 nurses in State Hospital, Ijaye. Each respondent was given an equal chance of participating in the study and an adequate number of nurses was represented in each cadre.

\section{Instrument for Data Collection}

Data was collected using a self-structured questionnaire. The questionnaire was drawn after an extensive literature review.

\section{Validity of the Instrument}

The questionnaire was self-constructed after a review of literature relevant to the subject matter and submitted to the supervisor for scrutiny and approval to ensure the faces, contents and construct validity of the instrument.

\section{Reliability of the Instrument}

Reliability was done by using a test-retest method before the researcher's final administration to the sample to consistently measure what it is meant to measure.

\section{Method of Data Collection}

A permission letter was collected from the school which was addressed to the Head of Nursing Department in State Hospital Ijaye, to obtain permission to carry out the study which was granted. The voluntary consent of the nurse was obtained. Questionnaires were administered and data were obtained for about 4 weeks.

\section{Method of Data Analysis}

Data obtained from the respondents were analyzed with the Statistical Package for Social Sciences (SPSS) version 22 and the analytical tools used were frequency, tables, bar chart, percentages and figures.

\section{Ethical Consideration}

An introductory and permission letter signed by the research's supervisor was taken to the Chief Medical Director of the State hospital Ijaye, through the Nursing Department in State Hospital 
Ijaye, to seek permission and telling them the purpose of the study. The respondents were informed about the purpose, aims and objectives of the study and they were allowed to make an informed decision on whether to participate or not. All ethical principles guiding the research process were adhered to. Informed consent from the correspondents' prior administration was ensured. The principle of confidentiality and anonymity was ensured, secured storage of the questionnaire was also ensured. Participants were informed that their participation is voluntary and they could withdraw from the study at any time if they wish to do so.

\section{RESULTS/FINDINGS}

Section A: Sociodemographic Characteristics

TABLE 1

\begin{tabular}{|c|c|c|c|}
\hline & & Frequency (f) & Per cent $(\%)$ \\
\hline \multirow{5}{*}{ Age in years } & $21-30$ & 38 & 38 \\
\hline & $31-40$ & 35 & 35 \\
\hline & $41-50$ & 18 & 18 \\
\hline & 51 and above & 9 & 9 \\
\hline & Total & 100 & 100 \\
\hline \multirow{3}{*}{ Gender } & Male & 19 & 19 \\
\hline & Female & 81 & 81 \\
\hline & Total & 100 & 100 \\
\hline \multirow{5}{*}{ Marital status } & Single & 44 & 44 \\
\hline & Married & 52 & 52 \\
\hline & Divorced & 4 & 4 \\
\hline & Widow & 0 & 0 \\
\hline & Total & 100 & 100 \\
\hline \multirow{4}{*}{ Tribe } & Yoruba & 87 & 87 \\
\hline & Igbo & 6 & 6 \\
\hline & Hausa & 7 & 7 \\
\hline & Total & 100 & 100 \\
\hline \multirow{4}{*}{ Religion } & Christianity & 67 & 67 \\
\hline & Islamic & 32 & 32 \\
\hline & Traditional & 1 & 1 \\
\hline & Total & 100 & 100 \\
\hline \multirow{7}{*}{ Rank } & NO II & 25 & 25 \\
\hline & NO I & 19 & 19 \\
\hline & SNO & 25 & 25 \\
\hline & $\mathrm{PNO}$ & 14 & 14 \\
\hline & ACNO & 11 & 11 \\
\hline & $\mathrm{CNO}$ & 6 & 6 \\
\hline & Total & 100 & 100 \\
\hline
\end{tabular}


Table 1 shows the demographic characteristics of respondents, $38 \%$ of the respondents were 21-30 years, $35 \%$ were $31-40$ years. $18 \%$ were $41-50$ years while only $9 \%$ were 51 and above years of age. $81 \%$ were females while $19 \%$ were males. $52 \%$ were also married, $44 \%$ were singles, $4 \%$ were divorced. $87 \%$ were Yorubas, $6 \%$ were Igbos were $7 \%$ were Hausa. $67 \%$ were Christians, $32 \%$ were Muslims while only $1 \%$ was a traditionalist. $25 \%$ each of the respondents was NO II and SNO, $19 \%$ were NO I, $14 \%$ were PNO, $11 \%$ were ACNO while only $6 \%$ were $\mathrm{CNO}$.

Section B: Job Characteristics

TABLE 2

\begin{tabular}{|c|c|c|c|}
\hline STATEMENTS & Responses & Frequency (f) & Per cent $(\%)$ \\
\hline \multirow{7}{*}{$\begin{array}{c}\text { How many years of nursing experience } \\
\text { do you have }\end{array}$} & $1-5$ & 52 & 52 \\
\hline & $6-10$ & 28 & 28 \\
\hline & $11-15$ & 6 & 6 \\
\hline & $16-20$ & 8 & 8 \\
\hline & $21-25$ & 5 & 5 \\
\hline & $26-30$ & 1 & 1 \\
\hline & Total & 100 & 100 \\
\hline \multirow{3}{*}{ How many hours do you work in a day? } & 6-10hrs & 67 & 67 \\
\hline & $11-15 \mathrm{hrs}$ & 33 & 33 \\
\hline & Total & 100 & 100 \\
\hline \multirow{4}{*}{ How many days do you work in a week? } & 1-3days & 35 & 35 \\
\hline & 4-6days & 59 & 59 \\
\hline & $\begin{array}{l}\text { More than } 6 \\
\text { days }\end{array}$ & 6 & 6 \\
\hline & Total & 100 & 100 \\
\hline \multirow{5}{*}{$\begin{array}{c}\text { Averagely, how many patients do you } \\
\text { care for in a day }\end{array}$} & $1-10$ & 67 & 67 \\
\hline & $11-20$ & 27 & 27 \\
\hline & $21-30$ & 4 & 4 \\
\hline & Above 30 & 2 & 2 \\
\hline & Total & 100 & 100 \\
\hline \multirow{3}{*}{$\begin{array}{l}\text { Do you meet conflicting demands at your } \\
\text { job? }\end{array}$} & Yes & 86 & 86 \\
\hline & No & 14 & 14 \\
\hline & Total & 100 & 100 \\
\hline \multirow{3}{*}{ Do you get social support at your job? } & Yes & 76 & 76 \\
\hline & No & 24 & 24 \\
\hline & Total & 100 & 100 \\
\hline \multirow{4}{*}{ Who gives the social support } & Government & 27 & 27 \\
\hline & Patients & 37 & 37 \\
\hline & NGOs & 12 & 12 \\
\hline & Total & 76 & 76 \\
\hline \multirow{3}{*}{$\begin{array}{l}\text { Do you get feedback when you raise your } \\
\text { concerns to the hospital management? }\end{array}$} & Yes & 63 & 63 \\
\hline & No & 37 & 37 \\
\hline & Total & 100 & 100 \\
\hline
\end{tabular}


Table 2 shows the job characteristics of respondents, $52 \%$ had 1-5 years of nursing experience, $28 \%$ had $6-10$ years, $8 \%$ had $16-20$ years, $6 \%$ had $11-15$ years while 0nly $1 \%$ had $26-30$ years. $67 \%$ used to work 6-10 hours a day, $33 \%$ used to work 11-15 hours a day. 59\% used to work 4-6 days a week, $35 \%$ used to work 1-3 days a week while $6 \%$ used to work more than 6 days a week. $67 \%$ used to see 1-10 patients in a day, $27 \%$ use to see $11-20$ patients in a day while $2 \%$ used to see above 30 patients. $86 \%$ claimed they used they do meet conflicting demands at their job while $14 \%$ hardly meet conflicting demands. $76 \%$ used to get social support at their job while $24 \%$ didn't get any. Out of the $76 \%$ who used to get social support, $37 \%$ used to get it from patients, $27 \%$ used to get it from the government while $12 \%$ used to get it from NGOs. $63 \%$ also used to get feedback when they raise concerns to hospital management while $37 \%$ didn't use to get feedback.

\section{Section C: Knowledge About Burnout}

TABLE 3

\begin{tabular}{|c|c|c|c|}
\hline STATEMENTS & Responses & Frequency (f) & Per cent $(\%)$ \\
\hline \multirow{3}{*}{$\begin{array}{c}\text { Have you ever received any education } \\
\text { about burnout? }\end{array}$} & Yes & 95 & 95 \\
\hline & No & 5 & 5 \\
\hline & Total & 100 & 100 \\
\hline \multirow{5}{*}{ Where did you learn about burnout? } & Nursing school & 35 & 36.8 \\
\hline & Seminars & 40 & 42.1 \\
\hline & Workplace & 10 & 10.5 \\
\hline & Media & 10 & 10.5 \\
\hline & Total & 95 & 100 \\
\hline
\end{tabular}

Table 3 shows the knowledge about burnout, 95\% had receive education about burnout while $5 \%$ had not. Out of the $95 \%$ who had received education about burnout, $42.1 \%$ learnt about it from seminars, $36.8 \%$ learnt it from nursing school while $10 \%$ each learnt it from the workplace and media.

TABLE 4

\begin{tabular}{|l|c|c|c|c|c|c|}
\hline \multicolumn{1}{|c|}{ DEFINITION OF BURNOUT } & $\begin{array}{c}\text { SA } \\
(\boldsymbol{\%})\end{array}$ & $\begin{array}{c}\text { A } \\
(\boldsymbol{\%})\end{array}$ & $\begin{array}{c}\text { SD } \\
(\boldsymbol{\%})\end{array}$ & $\begin{array}{c}\text { D } \\
(\boldsymbol{\%})\end{array}$ & $\begin{array}{c}\text { TOTAL } \\
\text { AGREE } \\
(\boldsymbol{\%})\end{array}$ & $\begin{array}{c}\text { TOTAL } \\
\text { DISAGREE } \\
(\boldsymbol{\%})\end{array}$ \\
\hline $\begin{array}{l}\text { Progressive loss of perfectionism, } \\
\text { energy and purpose as a result of } \\
\text { doing nursing work }\end{array}$ & 56 & 44 & 0 & 0 & 100 & 0 \\
\hline Ineffectiveness at work & 29 & 66 & 2 & 3 & 95 & 5 \\
\hline Response to work overload & 45 & 54 & 1 & 0 & 99 & \\
\hline A form of job stress & 36 & 60 & 4 & 0 & 96 & 4 \\
\hline
\end{tabular}


Table 5:

\begin{tabular}{|l|c|c|c|c|c|c|}
\hline $\begin{array}{l}\text { CAUSES OF NURSE BURNOUT } \\
\text { RELATED TO THE WORK }\end{array}$ & $\begin{array}{c}\text { SA } \\
\text { ENVIRONMENT }\end{array}$ & $\begin{array}{c}\text { A } \\
(\%)\end{array}$ & $\begin{array}{c}\text { SD } \\
(\%)\end{array}$ & $\begin{array}{c}\text { D } \\
(\%)\end{array}$ & $\begin{array}{c}\text { TOTAL } \\
\text { AGREE } \\
(\%)\end{array}$ & $\begin{array}{c}\text { TOTAL } \\
\text { DISAGREE } \\
(\%)\end{array}$ \\
\hline Working long hours & 51 & 48 & 0 & 1 & 99 & 1 \\
\hline $\begin{array}{l}\text { Feeling insufficiency trained for the } \\
\text { job }\end{array}$ & 35 & 60 & 1 & 4 & 95 & 5 \\
\hline $\begin{array}{l}\text { Lack of appreciation from } \\
\text { management }\end{array}$ & 43 & 52 & 0 & 5 & 95 & 5 \\
\hline $\begin{array}{l}\text { Having to perform administrative } \\
\text { duties }\end{array}$ & 38 & 56 & 3 & 3 & 94 & 6 \\
\hline Lack of reward for accomplishments & 43 & 52 & 1 & 4 & 95 & 5 \\
\hline Lack of respect from management & 42 & 49 & 1 & 8 & 91 & 9 \\
\hline $\begin{array}{l}\text { Reduced resources available to the } \\
\text { nurse }\end{array}$ & 38 & 53 & 7 & 2 & 91 & 9 \\
\hline $\begin{array}{l}\text { Lack of power in the decision- } \\
\text { making process }\end{array}$ & 43 & 50 & 2 & 5 & 93 & 7 \\
\hline $\begin{array}{l}\text { Not enough time to do the nurse's } \\
\text { standard }\end{array}$ & 39 & 53 & 6 & 2 & 92 & 8 \\
\hline Being left out of decision-making & 34 & 59 & 1 & 6 & 93 & 7 \\
\hline Violence from patients and families & 37 & 59 & 0 & 4 & 96 & 4 \\
\hline
\end{tabular}

Table 4 shows the definitions of burnout, all respondents (100\%) said it was progressive loss of perfectionism, energy and purpose as a result of doing nursing work. 95\% agreed that it was ineffectiveness at work, $99 \%$ and $96 \%$ also agreed respectively that it was a response to work overload and form of job stress.

The causes of nurse burnout related to the work environment are also displayed in Table 5, 99\% and 95\% agreed respectively that working long hours and feeling of insufficiency trained for the job were among causes of nurse burnout. 95\% agreed that lack of appreciation from management was among the causes, $94 \%$ and $95 \%$ agreed respectively that having to perform administrative duties and lack of reward for accomplishments was among the causes of burnout. 91\% each agreed that lack of respect from management and reduced resources available for nurses were among the causes of nurse burnout. 93\% also agreed that being left out of decision making was part of the causes of burnout. $96 \%$ agreed as well that violence from patients and families was among the causes of nurse burnout. 


\section{Table 6:}

\begin{tabular}{|l|c|c|c|c|c|c|}
\hline $\begin{array}{c}\text { THINGS A NURSE CAN DO } \\
\text { TO PREVENT BURNOUT }\end{array}$ & $\begin{array}{c}\text { SA } \\
(\boldsymbol{\%})\end{array}$ & $\begin{array}{c}\text { A } \\
(\boldsymbol{\%})\end{array}$ & $\begin{array}{c}\text { SD } \\
(\boldsymbol{\%})\end{array}$ & $\mathbf{D}(\boldsymbol{\%})$ & $\begin{array}{c}\text { TOTAL } \\
\text { AGREE } \\
(\boldsymbol{\%})\end{array}$ & $\begin{array}{c}\text { TOTAL } \\
\text { DISAGREE } \\
(\%)\end{array}$ \\
\hline $\begin{array}{l}\text { Increase knowledge of positive } \\
\text { coping strategies }\end{array}$ & 61 & 34 & 0 & 5 & 95 & 5 \\
\hline Establish social support & 38 & 56 & 0 & 6 & 94 & 6 \\
\hline Set realistic goals for self & 49 & 50 & 0 & 1 & 99 & 1 \\
\hline Address issues with co-workers & 52 & 44 & 2 & 2 & 96 & 4 \\
\hline Be assertive promptly & 56 & 34 & 7 & 3 & 90 & 10 \\
\hline Be respectful towards others & 57 & 40 & 0 & 3 & 97 & 3 \\
\hline Maintain a positive attitude & 47 & 48 & 3 & 2 & 95 & 5 \\
\hline $\begin{array}{l}\text { Practice good communication } \\
\text { skills }\end{array}$ & 49 & 49 & 1 & 1 & 98 & 2 \\
\hline Regulate his or her emotions & 52 & 44 & 1 & 3 & 96 & 4 \\
\hline Get enough rest & 55 & 42 & 1 & 2 & 97 & 3 \\
\hline Healthy diet and exercise & 54 & 45 & 0 & 1 & 99 & 1 \\
\hline $\begin{array}{l}\text { Become aware and involved in } \\
\text { burnout prevention measures }\end{array}$ & 60 & 40 & 0 & 0 & 100 & 0 \\
\hline $\begin{array}{l}\text { Create a healthy work } \\
\text { environment }\end{array}$ & 48 & 52 & 0 & 0 & 100 & 0 \\
\hline
\end{tabular}

Table 6 shows the things a nurse can do to prevent burnout, 95\% and 94\% agreed respectively that increase knowledge of positive coping strategies and establishing social support were among what a nurse can do to prevent burnout. 99\% agreed that setting realistic goals prevent burnout. $96 \%$ and $90 \%$ agreed respectively that addressing issues with co-workers and being assertive can prevent burnout. 98\% agreed that practising good communication can prevent burnout. $97 \%$ and $95 \%$ agreed that being respectful and positive attitude can prevent burnout respectively. 96\% also agreed that regulating his/her emotions can prevent burnout. 97\% agreed that getting enough rest prevents burnout. 99\% agreed that a healthy diet and exercise also prevents burnout. All respondents (100\%) agreed that becoming become aware and involved in burnout prevention measures and creating a healthy work environment prevents burnout.

Table 7:

\begin{tabular}{|l|c|c|c|c|c|c|}
\hline $\begin{array}{c}\text { THINGS A NURSE CAN DO } \\
\text { FOR SELF TO TREAT } \\
\text { REVERSE BURNOUT }\end{array}$ & $\begin{array}{c}\text { SA } \\
(\boldsymbol{\%})\end{array}$ & $\begin{array}{c}\text { A } \\
(\boldsymbol{\%})\end{array}$ & $\begin{array}{c}\text { SD } \\
(\boldsymbol{\%})\end{array}$ & $\begin{array}{c}\text { D } \\
(\boldsymbol{\%})\end{array}$ & $\begin{array}{c}\text { TOTAL } \\
\text { AGREE } \\
(\boldsymbol{\%})\end{array}$ & $\begin{array}{c}\text { TOTAL } \\
\text { DISAGREE } \\
(\boldsymbol{\%})\end{array}$ \\
\hline Adjusting self-expectations & 43 & 57 & 0 & 0 & 100 & 0 \\
\hline Improve his or her coping skills & 37 & 61 & 1 & 1 & 98 & 2 \\
\hline Practice positive thinking & 64 & 35 & 0 & 1 & 99 & 1 \\
\hline Be involved in committees & 59 & 40 & 0 & 1 & 99 & 1 \\
\hline Improve delegating skills & 62 & 34 & 4 & 0 & 96 & 4 \\
\hline
\end{tabular}


Table 7 shows the things a nurse can do for self to treat or reverse burnout. All respondents $(100 \%)$ agreed that adjusting self-expectations can treat or reverse burnout, $98 \%$ also agreed that improving his/her coping skills help to reverse burnout. 99\% each agreed that practising positive thinking and involving in committees help to reverse burnout. $96 \%$ also agreed that improving delegating skills helps a nurse to treat or reverse burnout.

\section{Section D: Job-Related Feelings}

\section{TABLE 8:}

KEYS: 0- Never

1- A few times a year or less

2- Once a month or less

3- A few times a month

4- Once a week

5- A few times a week

6- Every day

\begin{tabular}{|l|c|c|c|c|c|c|c|}
\hline & $\mathbf{0}(\boldsymbol{\%})$ & $\mathbf{1}(\boldsymbol{\%})$ & $\mathbf{2 ( \% )}$ & $\mathbf{3}(\mathbf{\%})$ & $\mathbf{4}(\mathbf{\%})$ & $\mathbf{5}(\mathbf{\%})$ & $\mathbf{6}(\mathbf{\%})$ \\
\hline $\begin{array}{l}\text { I feel emotionally drained from } \\
\text { my work }\end{array}$ & 6 & 4 & 12 & 9 & 16 & 20 & 33 \\
\hline $\begin{array}{l}\text { I feel fatigued when I get up in } \\
\text { the morning and have to face } \\
\text { another day on the job }\end{array}$ & 0 & 9 & 5 & 36 & 14 & 24 & 12 \\
\hline $\begin{array}{l}\text { I deal very effectively with the } \\
\text { problems of my patients }\end{array}$ & 0 & 7 & 15 & 20 & 26 & 12 & 20 \\
\hline I feel burned out from my work & 1 & 13 & 4 & 22 & 21 & 24 & 15 \\
\hline I feel very energetic & 3 & 17 & 13 & 22 & 15 & 13 & 17 \\
\hline $\begin{array}{l}\text { I feel I'm working too hard on } \\
\text { my job }\end{array}$ & 0 & 13 & 13 & 22 & 25 & 10 & 17 \\
\hline $\begin{array}{l}\text { Working with people directly } \\
\text { put too much stress on me }\end{array}$ & 6 & 12 & 13 & 19 & 28 & 12 & 10 \\
\hline $\begin{array}{l}\text { I can easily create a relaxed } \\
\text { atmosphere with my patients }\end{array}$ & 1 & 5 & 17 & 19 & 30 & 12 & 16 \\
\hline $\begin{array}{l}\text { I have accomplished many } \\
\text { worthwhile things in this job }\end{array}$ & 0 & 10 & 9 & 21 & 21 & 18 & 21 \\
\hline $\begin{array}{l}\text { In my work, I deal with } \\
\text { emotional problems very calmly }\end{array}$ & 3 & 12 & 13 & 17 & 21 & 12 & 22 \\
\hline $\begin{array}{l}\text { I feel patients blame me for } \\
\text { some of their problems }\end{array}$ & 9 & 13 & 24 & 16 & 12 & 17 & 9 \\
\hline
\end{tabular}

Table 8 shows job-related feelings among respondents, 33\% said they feel emotionally drained from their work every day, $20 \%$ said a few times in a week, $12 \%$ said once in a month or less, $9 \%$ said a few times in a month while $6 \%$ said never. $36 \%$ also said that they feel fatigued in the morning and have to face another day on the job a few times in a month, $24 \%$ used to feel it a few times in a week, $14 \%$ and $12 \%$ used to feel it once in a week and every day respectively while $9 \%$ used to feel it a few times a year or less. $26 \%$ and $20 \%$ said they used to deal very 
effectively with the problems of their patients once a week and a few times a month respectively, another $20 \%$ said they deal very effectively with problems from work every day while only $7 \%$ said a few times a year or less. $22 \%$ used to feel burned out of their work, energetic and felt they are working too hard on their job a few times. $28 \%$ said working directly with people put too much stress on them once in a week, $19 \%$ said a few times in a month, $12 \%$ and $10 \%$ said a few times a week and every day while $6 \%$ said never.

Also from Table $8,30 \%$ of the respondents said they can easily create a relaxed atmosphere with patients once a week, $19 \%$ said a few times a month, $16 \%$ said every day, $12 \%$ said a few times a week, $5 \%$ said once a month or less while $1 \%$ said never. $21 \%$ each said they have accomplished many worthwhile things in their job a few times a month and once a week respectively and every day, $17 \%$ said a few times a month, $13 \%$ and $12 \%$ said once a month or less and a few times a year or less respectively. $22 \%$ said they deal with emotional problems very calmly every day, $21 \%$ deal with it once a week, $17 \%$ said a few times a month, $13 \%$ said once a month or less while $3 \%$ said never. $24 \%$ said they feel patients blame them for some of their problems once a month or less, $17 \%$ said a few times a week, $16 \%$ said a few times a month while $13 \%$ and $9 \%$ said once a month or less and never respectively. $9 \%$ also said they feel patients blame them for their problems every day.

\section{RESEARCH QUESTIONS}

\section{What is the level of knowledge of professional burnout among clinical nurses?}

Table 8 shows the level of burnout among respondents, 33\% said they feel emotionally drained from their work every day, $20 \%$ said a few times in a week, $12 \%$ said once in a month or less, $9 \%$ said a few times in a month while $6 \%$ said never. $36 \%$ also said that they feel fatigued in the morning and have to face another day on the job a few times in a month, $24 \%$ used to feel it a few times in a week, $14 \%$ and $12 \%$ used to feel it once in a week and every day respectively while $9 \%$ used to feel it a few times a year or less. $26 \%$ and $20 \%$ said they used to deal very effectively with the problems of their patients once a week and a few times a month respectively, another $20 \%$ said they deal very effectively with problems from work every day while only $7 \%$ said a few times a year or less. $22 \%$ used to feel burned out of their work, energetic and felt they are working too hard on their job a few times. $28 \%$ said working directly with people put too much stress on them once in a week, $19 \%$ said a few times in a month, $12 \%$ and $10 \%$ said a few times a week and every day while $6 \%$ said never. Also from Table $8,30 \%$ of the respondents said they can easily create a relaxed atmosphere with patients once a week, $19 \%$ said a few times a month, $16 \%$ said every day, $12 \%$ said a few times a week, $5 \%$ said once a month or less while $1 \%$ said never. $21 \%$ each said they have accomplished many worthwhile things in their job a few times a month and once a week respectively and every day, $17 \%$ said a few times a month, $13 \%$ and $12 \%$ said once a month or less and a few times a year or less respectively. $22 \%$ said they deal with emotional problems very calmly every day, $21 \%$ deal with it once a week, $17 \%$ said a few times a month, $13 \%$ said once a month or less while $3 \%$ said never. $24 \%$ said they feel patients blame them for some of their problems once a month or less, $17 \%$ said a few times a week, $16 \%$ said a few times a month while $13 \%$ and $9 \%$ said once a month or less and never respectively. $9 \%$ also said they feel patients blame them for their problems every day. 


\section{What are the causes of burnout among clinical nurses?}

The causes of nurse burnout related to the work environment are also displayed in Table 5, 99\% and 95\% agreed respectively that working long hours and feeling of insufficiency trained for the job were among causes of nurse burnout. 95\% agreed that lack of appreciation from management was among the causes, $94 \%$ and $95 \%$ agreed respectively that having to perform administrative duties and lack of reward for accomplishments was among the causes of burnout. 91\% each agreed that lack of respect from management and reduced resources available for nurses were among the causes of nurse burnout. $93 \%$ also agreed that being left out of decision making was part of the causes of burnout. $96 \%$ agreed as well that violence from patients and families was among the causes of nurse burnout.

\section{What is the level of prevention and ways to reverse burnout among clinical nurses?}

Table 6 shows the things a nurse can do to prevent burnout, 95\% and 94\% agreed respectively that increase knowledge of positive coping strategies and establishing social support were among what a nurse can do to prevent burnout. 99\% agreed that setting realistic goals prevent burnout. $96 \%$ and $90 \%$ agreed respectively that addressing issues with co-workers and being assertive can prevent burnout. 98\% agreed that practising good communication can prevent burnout. $97 \%$ and $95 \%$ agreed that being respectful and positive attitude can prevent burnout respectively. 96\% also agreed that regulating his/her emotions can prevent burnout. 97\% agreed that getting enough rest prevents burnout. 99\% agreed that a healthy diet and exercise also prevents burnout. All respondents (100\%) agreed that becoming become aware and involved in burnout prevention measures and creating a healthy work environment prevents burnout. Table 7 shows the things a nurse can do for self to treat or reverse burnout. All respondents (100\%) agreed that adjusting self-expectations can treat or reverse burnout, 98\% also agreed that improving his/her coping skills help to reverse burnout. $99 \%$ each agreed that practising positive thinking and involving in committees help to reverse burnout. $96 \%$ also agreed that improving delegating skills helps a nurse to treat or reverse burnout.

\section{CONCLUSION}

According to the findings from this study, burnout prevails among staff nurses. Healthcare organizations and management need to acknowledge the problem of work-related stress and provide the much-needed appropriate measures. Examining nurses' working conditions and ensuring the availability of resources is likely to improve job satisfaction, decrease turnover and intent to leave. Favourable working conditions and a good nursing profession image may attract people to consider a career in nursing. Aside from free study grants, job opportunities etc. which are most likely to attract young people, what can be done to retain nurses, improve job satisfaction, patient safety, quality of health care and quality of life for both nurses and patients. 


\section{RECOMMENDATIONS}

It is recommended that longitudinal studies should be carried out to investigate the mediating pathways, causality and effects between socio-demographic \& work-related characteristics and disorders among nurses. There is also a need for more intervention studies to test whether modifying the work-related variables/stressors will lead to better mental health and workout in the working populations. Finally, there is a need to create awareness of the disorder among health workers and to provide stress management services to healthcare professionals with an emphasis on stress prevention and creating a salutary hospital environment.

\section{Suggestion For Further Studies}

The study will, however, allow for comparison with data available in sub-Saharan Africa and serve as a source of information for comparison with other future studies on burnout to be conducted in Nigeria. Future studies should be large-scaled, multi-centred and multi-levelled so as to reduce the effect of the biases in this study.

\section{REFERENCES}

Adriaenssens J., De Gucht V., Maes S. (2012). Causes and consequences of occupational stress in emergency nurses, a longitudinal study. J. Nurs. Manag. 57, 151-160. 10.1111/jonm.12138 [PubMed] [CrossRef] [Google Scholar].

Albaladejo R., Villanueva P., Ortega P, (2004). The relationship between experiential voidance and burnout syndrome in critical care nurses: A cross-sectional questionnaire survey.

Alexander D., Ford M. T., Matthews R. A., Wooldridge J. D., Mishra V., Kakar U. M Strahan S.R.(2012). How do occupational stressor-strain effects vary with time? A review and meta-analysis of the relevance of time lag in longitudinal studies. Work Stress 28, 9 30. 10.1080/02678373.2013.877096

Bakker and Demerouti. (2006): The Job Demands-Resources model: state of the art. Journal of Managerial Psychology; 22(3), 309-328.

Baldonedo-Mosteiro M., Cristina M. (2019). Burnout Syndrome in Brazilian and SpanishNursing workers. 2019:31(4):225-233.

Chanu NJ, Shiroor G (2019): Burnout among staff nurses working in hospitals The Pharma Innovation Journal; 8(6): 312-315

Cox T., Griffiths A., (2016). Work-related stress in nursing: Controlling the risk to health Working paper, International Labour Office: Geneva, Switzerland.

Edwards, D., Burnard, P., Coyle, D., Fothergill, A., Hannigan, B., (2010). Stress and burnout in community health nursing: a review of the literature. Journal of Psychiatric and Mental Health Nursing. 7, pp.7-14.

Ewers P., Bradshaw, T., McGovern, J., Ewers, B. (2012). Does training in psychosocial interventions reduce burnout rates in forensic nurses? Journal of Advanced Nursing 37(5), pp.470476.

Hall E., (2010). Nurse burnout in a high-stress health care environment: prognosis better than expected? Unpublished working paper, University of Otago, New Zealand.

Harrowing J., (2011). Compassion Practice by Ugandan Nurses Who Provide HIV Care. OJIN: $\quad$ The Online Journal of Issues in Nursing. 16(1), 5 
ICN, (2009). ICN on occupational stress and the threat to worker health. Nursing matters. ICN: Geneva, Switzerland.

Jennings B.M. (2008). Work Stress and Burnout Among Nurses: Role of the Work Environment and Working Conditions. In: HUGHES, R. G., (ed), Patient Safety and Quality: An Evidence-Based Handbook for Nurses. Rockville, MD: Agency for healthcare research and quality.

Kanter R. A. (1993). Job Content Questionnaire and User's Guide (Revision 1.1). Lowell, MA: University of Massachusetts Lowell, the Job Content Questionnaire Center. [Google Scholar].

Lang G.M., (2007). The Work Environment of Army Hospital Nurses: Measurement and Construct Validity. pp. $51-52$

Leiter M.P., Maslach C., (2010). Nurse turnover: the mediating role of burnout. Journal of Nursing Management. 17, pp.331-339

Lundmark, V.A., (2010). Magnet Environments for Professional Nursing Practice In: Patient Safety and Quality: An Evidence-Based Handbook for Nurses.

Martha Nabadda (2012): Knowledge and perception toward professional burnout among nurses caring for patients with terminal illnesses at Hospice Africa Uganda and Uganda Cancer Institute.

Maslach C., Jackson S.E., (2011). The measurement of experienced burnout. Journal of occupational behaviour. 2, pp.99-113

Pisanti R., Pereda-Torales D., Lombardo C., Lucidi F., Violani C., Lazzari D. (2009). Psychometric properties of the Maslach Burnout Inventory for human services among Italian nurses: a test of alternative models. J. Adv. Nurs. 69, 697-707. 10.1111/j.1365 2648.2012.06114.

Renzi C., Di Pietro C., Tabolli S. (2012). Psychiatric morbidity and emotional exhaustion among hospital physicians and nurses: association with perceived job-related factors. Arch. Environ. Occup. Health 67, 117-123. 10.1080/19338244.2011.578682 [PubMed] [CrossRef] [Google Scholar]

Schmidt K.H., Diesel S. (2012). Differential effects of decision latitude and control on the job demand-strain relationship: a cross-sectional survey study among elderly care nursing staff. Int. J. Nurs. Stud. 48, 307-317. 10.1016/j.ijnurstu.2010.04.003 [PubMed] [Cross Ref] [Google Scholar]

Stewart, K. L., (2009). Nurse managers' knowledge of staff nurse burnout. Unpublished master's thesis, Western Carolina University, USA.

Vahey, D.C., Aiken, L.H., Sloane, D.M., Clarke, S.P., Vargas, D., (2014). Nurse Burnout and Patient Satisfaction. Medical Care. 42(2), pp.57-66

Van der Colf P., Van Heusden D., Rothmann O., Franck E. (2009). Nurse work engagement impacts job outcome and nurse-assessed quality of care: model testing with nurse practise environment and nurse work characteristics as predictors. Front. Psychol. 5:1261. 10.3389/fpsyg.2014.01261.

Van Der Doef, M., Mbazz, F. B., Verhoeven, C., (2012). Job conditions, job satisfaction, somatic complaints and burnout among East African nurses. Journal of Clinical Nursing. 21, pp.1763-1775 